\title{
A Review of the Health Protective Effects of Phenolic Acids against a Range of Severe Pathologic Conditions (Including Coronavirus-Based Infections)
}

\author{
Sotirios Kiokias $^{1, *}$ and Vassiliki Oreopoulou ${ }^{2}$ (D) \\ 1 European Research Executive Agency, Place Charles Rogier 16, 1210 Bruxelles, Belgium \\ 2 Laboratory of Food Chemistry and Technology, School of Chemical Engineering, \\ National Technical University of Athens, Iron Politechniou 9, 15780 Athens, Greece; vasor@chemeng.ntua.gr \\ * Correspondence: Sotirios.Kiokias@ec.europa.eu; Tel.: +32-49-533-2171
}

\section{check for}

updates

Citation: Kiokias, S.; Oreopoulou, V. A Review of the Health Protective Effects of Phenolic Acids against a Range of Severe Pathologic

Conditions (Including

Coronavirus-Based Infections) Molecules 2021, 26, 5405. https:// doi.org/10.3390/molecules26175405

Academic Editors: Maria José Rodríguez-Lagunas and Malen Massot-Cladera

Received: 23 July 2021

Accepted: 12 August 2021

Published: 6 September 2021

Publisher's Note: MDPI stays neutral with regard to jurisdictional claims in published maps and institutional affiliations.

Copyright: (c) 2021 by the authors. Licensee MDPI, Basel, Switzerland. This article is an open access article distributed under the terms and conditions of the Creative Commons Attribution (CC BY) license (https:// creativecommons.org/licenses/by/ $4.0 /)$.

\begin{abstract}
Phenolic acids comprise a class of phytochemical compounds that can be extracted from various plant sources and are well known for their antioxidant and anti-inflammatory properties. A few of the most common naturally occurring phenolic acids (i.e., caffeic, carnosic, ferulic, gallic, p-coumaric, rosmarinic, vanillic) have been identified as ingredients of edible botanicals (thyme, oregano, rosemary, sage, mint, etc.). Over the last decade, clinical research has focused on a number of in vitro (in human cells) and in vivo (animal) studies aimed at exploring the health protective effects of phenolic acids against the most severe human diseases. In this review paper, the authors first report on the main structural features of phenolic acids, their most important natural sources and their extraction techniques. Subsequently, the main target of this analysis is to provide an overview of the most recent clinical studies on phenolic acids that investigate their health effects against a range of severe pathologic conditions (e.g., cancer, cardiovascular diseases, hepatotoxicity, neurotoxicity, and viral infections-including coronaviruses-based ones).
\end{abstract}

Keywords: phenolic acids; antioxidants; health properties

\section{Introduction}

Free radicals are mainly reactive oxygen species (ROS) (including hydroxyl-, superoxideradicals and singlet oxygen) that are formed in tissue cells by various endogenous and exogenous pathways. ROS normally exert an adverse impact on human health by inducing the so called "oxidative stress conditions" [1]. The ability of free radicals to structurally modify cellular components and cause oxidative damage to biomolecules (LDL-low density lipoproteins, DNA, etc.) has revealed their involvement in a variety of health pathologies (i.e., inflammation, aging, types of cancer and cardiovascular diseases) [2,3].

Nature has generously offered several types of natural dietary antioxidants, among which phenolic compounds can operate as scavengers of free radicals in vivo and can efficiently reduce the harmful health impacts of oxidative damage [4,5]. Phenolic acids comprise a group of natural phenolic compounds that are present in a wide range of herbs and other species of the plant kingdom [6]. More specifically, thyme, oregano, rosemary, sage, and mint herbal preparations - all rich in various phenolics-have been reported to exert strong antioxidant biochemical and anti-inflammatory properties [7,8]. A few authors have reviewed the radical scavenging capacity of phenolic acids and their subsequent beneficial effects against the development of cancer, cardiovascular diseases and other health disorders (such as skin problems, inflammations, bacterial infections, etc.) [9]. The main biochemical pathways and mechanisms of phenolic actions against the development of certain types of cancer include: free radical scavenging, enzyme induction, DNA damage repair, cell proliferation depression, and apoptosis [10].

In their recent publication, Kiokias et al. (2020) [11] focused on the in vitro antioxidant activities of a few common naturally occurring phenolic acids (caffeic, carnosic, ferulic, 
gallic, p-coumaric, rosmarinic, vanillic) against the oxidation of oil-in-water emulsions. Such interfacial lipid-based systems generally mimic the structure of biological membranes and biomolecules that when attacked by free radicals are prone to harmful in vivo oxidative reactions.

In this paper, the authors first report on the main structural features of phenolic acids as well as on a few important natural sources and their extraction techniques. Subsequently, the main focus of this analysis is to provide an overview of the most recent clinical studies on phenolic acids that investigate their health effects against a few severe pathologic disorders.

\section{Structure, Herbal Sources and Extraction of the Most Common Naturally Occurring} Phenolic Acids

\subsection{Structural Classidication of Natural Phenolic Acids}

In terms of their chemical structure, phenolic acids are classified as:

Hydroxybenzoic acids with a $\mathrm{C}_{6}-\mathrm{C}_{1}$ structure: Among them a trihydroxy derivative (gallic acid) has been associated with tea antioxidant activity, while vanilic acid is a methoxyhydroxy derivative serving as a well-known flavouring agent [12].

Hydroxycinnamic acids with a $\mathrm{C}_{6}-\mathrm{C}_{3}$ structure [13]. These are abundant in plant sources, with p-coumaric (4-hydroxy derivative), caffeic (3,4-dihydroxy derivative) and ferulic (3-methoxy, 4-hydroxy derivative) commonly present in various culinary herbs. In addition, rosmarinic acid (an ester of caffeic acid with 3,4-dihydroxyphenyl lactic acid) is mainly encountered in certain aromatic herbs [14].

Phenylacetic acids with a $\mathrm{C}_{6}-\mathrm{C}_{2}$ structure. Phenylacetic acids are scarce in fruits and vegetables, while a dihydroxy derivative was detected in strawberry tree honey [15]. Carnosic acid belongs to the phenolic diterpenes that are usually classified as hybrid phenolics [13].

This review focuses on the most common hydroxybenzoic and hydroxycinnamic phenolic acids, along with carnosic acid, the chemical structures of which are given in Figure 1.

(a) Hydrocinnamic acids

Caffeic acid<smiles>O=C(O)/C=C/c1ccc(O)c(O)c1</smiles>

Ferulic acid<smiles>COc1cc(/C=C/C(=O)O)ccc1O</smiles>

p-Coumaric acid

Rosmarinic acid (b) Hydroxybenzoic acids<smiles>O=C(O)c1cc(O)c(O)c(O)c1</smiles><smiles>COc1cc(C(=O)O)ccc1O</smiles>

Carnosic acid

(hybrid phenolic)

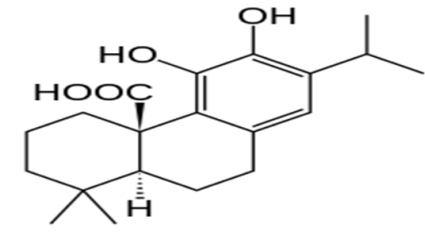

Figure 1. Chemical structure of phenolic acids examined in this study. 


\subsection{Herbal Sources and Extraction of Phenolic Acids}

Caffeic acid (CA) is found at high levels in various herbs worldwide, including the South American herb yerba mate $(1.5 \mathrm{~g} / \mathrm{kg})$ [16], the Japanese herbal leaf tea, the tea stem from Moringa oleifera L. [17], and thyme (1.7 mg/kg) [18].

Carnocic acid (CarA) can be found in a few species of the Lamiaceae family (such as rosemary and common salvia species). It has been reported to be present at a concentration of 1.5 to $2.5 \%$ in dried sage leaves $[19,20]$.

Ferulic acid (FA) is present in black beans at an average concentration of $0.8 \mathrm{~g} / \mathrm{kg}$, while flaxseed has been reported as the richest natural source of FA glucoside $(4.1 \pm 0.2 \mathrm{~g} / \mathrm{kg}),[21,22]$. FA has been also identified as the major phenolic acid in Angelica sinensis (Oliv.), a traditional medicinal and edible plant in China [23].

Gallic acid (GA) has been found to be the main phenolic acid in tea [24] but also reported in high amounts in the parasitic plant Cynomorium coccineum, the aquatic plant Myriophyllum spicatum, and the blue-green alga Microcystis aeruginosa [25]. In addition, GA was recently identified as the main phenolic compound in leaf extracts from the medicinal halophyte Thespesia populnea tea [26].

p-Coumaric acid (p-CA) has been identified in basil, garlic [27] and in amaranth leaves and stem at a concentration range of $28-44 \mathrm{mg} / \mathrm{kg}$ [28]. p-CA has been reported as the major active compound in Bambusae Caulis, a Chinese medicinal herb [29] as well as in cultivars of husked oat (Avena sativa L.) in Finland [30].

Rosmarinic acid (RA) is the main phenolic component in several members of the Lamiaceae family, including among others: Rosmarinus officinalis, Origanum spp., Perilla spp., and Salvia officinialis in concentrations varying between 0.05 and $26 \mathrm{~g} / \mathrm{kg}$ dry weight [31]. Additionally, the results of Tsimogiannis et al. [32] indicate an amount of $19.5 \mathrm{~g} / \mathrm{kg}$ in the leaves of pink savoury (Satureja thymbra L.).

Vanillic Acid (VA) is commonly found in several fruits, olives, and cereal grains (e.g., whole wheat), as well as in wine. VA was also identified in fruit extracts of the açaí palm plant (Euterpe oleracea) [33] and in the root of Angelica sinensis (an herb indigenous to China) at concentrations between 1.1 and $1.3 \mathrm{~g} / \mathrm{kg}$ [34].

\subsection{Extraction of Phenolic Acids from Their Natural Sources}

The extraction and identification of phenolic acids has been studied by various researchers [35,36]. Phenolic acids are compounds with medium to high polarity and, therefore, can be extracted by water [37]. Nevertheless, aqueous solutions of ethanol or acetone $(50-70 \%)$ are the best solvents for the quantitative extraction of hydrocinnamic acids [38]. On the contrary, CarA exhibits low polarity and is quantitatively extracted with the use of pure acetone or ethanol [39].

Hydroxycinnamic and hydroxybenzoic acids may be linked to polysaccharides of the cell walls by ester bonds and to lignin components by ester or ether bonds [40]. Mild alkaline hydrolysis can be implied to cleave the ester bonds, while acid hydrolysis to cleave the ether bonds and release the phenolic acids [41]. However, phenolic acids may be degraded under alkaline conditions, e.g., RA has been reported to transform to CA [42]. Additionally, mild temperature and time combinations are suggested to avoid degradation. The most prone to degradation is CarA, which is oxidised to carnosol (which also exhibits antioxidant activity) at temperatures higher than $50{ }^{\circ} \mathrm{C}$ and at longer extraction times [43].

In addition to conventional solid liquid extraction, ultrasound assisted extraction and microwave assisted extraction proved even more effective for phenolic acid extraction, while shortening extraction time [44,45].

The predominant role of high-performance liquid chromatography (HPLC) in the definition of the phenolic profile of various plant sources has been recently examined by Ciulu et al. (2018) [46], who also present the most recently developed mass spectrometrybased detection systems. In addition, the various developed procedures for the quantification of phenolic compounds have been described in the literature, along with the spectrophotometric protocols for the evaluation of their antioxidant properties [47,48]. 


\section{Biochemical and Health Properties of the Examined Phenolic Acids}

The leading cause of a few severe human health disorders is oxidative stress, a consequence of overproduction and accumulation of free radicals [49]. Naturally occurring polyphenols have been shown to possess a number of biological activities such as antibacterial, antiviral, anticancer, and anti-cholesterol properties [50]. This section reports on the most recent in vitro (in human cell lines) and in vivo (clinical animal) trials on phenolic acids. The analysis focuses on the specific health diseases, i.e., cardiovascular diseases, cancer, hepatotoxicity, neurodegenerative disorders, and microbial or viral infections including COVID-19, that all together account for the majority of deaths in the western world. The main research findings about the clinical effects of phenolic acids per health disease are discussed in the following paragraphs while a summary of the most recent studies is presented in the overview Tables (Tables 1 and 2).

\subsection{Effects against Cancer}

Globally, cancer is the second leading cause of death. In the continuous search for safer and more effective treatments than chemotherapy or radiotherapy, plant phenolic acids have gained importance displaying a great prospective as cytotoxic anti-cancer agents promoting apoptosis, reducing proliferation, and targeting various aspects of cancer [51].

\subsubsection{Individual Phenolic Acids}

The chemical structure of CA and mainly the presence of free phenolic hydroxyls is believed to strongly account for its antioxidant capacities that, in turn, link to certain anti-carcinogenic properties [52]. According to the literature, though, CA phenyl ester (CAPE) is actually the natural CA derivative with the most dominant anticancer activities. Wang et al. [53] reported a significantly enhanced suppression of tumour growth in mice treated with CAPE based nanoparticles, revealing thereby its potential use in anticancer nanomedicine.

Zhang et al. [54] observed that FA significantly decreased tumour volume and increased apoptosis in an MDA-MB-231 xenograft mouse model, thereby acting as an effective therapeutic agent against breast cancer. More recently, Al-Mutairi et al. [55] investigated the combination effect of lower doses of thymoquinone and FA on the proliferation, apoptosis, and cell cycle of breast cancer cell line MDA-MB-231. The authors reported that either $25 \mu \mathrm{M}$ of thymoquinone or $250 \mu \mathrm{M}$ of FA, individually, had no effect but in combination significantly reduced cell proliferation, thus exerting an anticancer therapeutic potential. Solomonov et al. [56] demonstrated a significant anti-inflammatory effect of CarA combined with astaxanthin and a lycopene-rich tomato extract in a nutrient supplementation.

Sung and Wang [57] treated human cells (EC9706 and KYSE450) with different GA concentrations $(10,20$, and $40 \mu \mathrm{g} / \mathrm{mL})$. According to the results, GA decreased the growth of xenograft tumour in vivo and promoted cell apoptosis in a concentration-dependent manner. Sales et al. [58] conducted a study to evaluate the effect of GA isolated from methanolic fruit extract of Terminalia bellirica to inhibit the survival of breast cancer cells (MCF-7 \& MDA-MB-231). The authors reported that GA at $80 \mu \mathrm{M}$ exhibited decreased the survival of cancer cells and induced apoptosis, revealing its potential as an anticancer agent to be further explored for breast cancer drugs.

The anticancer and antitumoral properties of RA have been reviewed by Afonso et al. [59]. During 2020, two new clinical animal studies were conducted on RA. Luo et al. [60] reported that RA inhibited the proliferation and negatively affected the migratory potential of human oral cancer cells (cell line SCC-15) with a dose-dependent effect. Messeha et al. [61] reported that RA caused significant cytotoxic and antiproliferative effects in two racially different triple-negative breast cancer (TNBC) cell lines in a dose- and time-dependent manner.

Anbalagan et al. [62] explored the antioxidant efficacy of VA in dimethylbenz[a]anthracene (DMBA)-induced oral carcinogenesis. Supplementation with VA ( $200 \mathrm{mg} / \mathrm{kg}$ body weight) for 14 weeks significantly restored the disturbances in antioxidant status \{superoxide dismutase, catalase) to near normal range in DMBA treated hamsters. 
Furthermore, in vivo experiments confirmed that treatment with VA caused significant inhibition of tumour growth in a xenografted tumour model [63]. The in vitro antioxidant capacity of VA was demonstrated through the reduced DNA damage, induced by $\mathrm{H}_{2} \mathrm{O}_{2}$ in human lymphocytes at concentrations of $0.17-67.2 \mu \mathrm{g} / \mathrm{mL}$ [64]. These studies reveal that VA provides new perspectives of phenolic antitumour activity.

\subsubsection{Natural Extracts Rich in Phenolic Acids}

A body of research has been conducted in recent years about the anticancer properties of herbal extracts rich in various phenolic acids. Jeong et al. [65] observed clear therapeutic effects of polyphenolic mixtures (containing among others GA, p-CA and ellagic acid) against lung cancer cells.

Hydroxycinnamic acid derivatives of mulberry fruits were reported to increase the production of reactive oxygen species by acting as pro-oxidants and hence killing the cancer cells [66]. In another study, p-CA rich methanolic extracts of Amaranthus spinosus and of Amaranthus caudatus L. were shown to possess significant anti-inflammatory activity in mouse models [67]. Fernadez et al. [68] have reported that bael (Aegle marmelos) flowers and tulsi (Ocimum tenuiflorum) seeds (rich in GA, p-CA, CA and VA) present a strong antioxidant character against DNA damage.

Koyuncu [69] conducted a study on human colon (DLD-1), endometrium (ECC-1) cancer cells and embryonic kidney (HEK-293) cells to examine the anti-cancer and antioxidant properties of the methanolic extract obtained from Artemisia absinthium L. species. According to the results, the $A$. absinthium extract, rich in various phenolic acids, showed an antioxidant effect and a cytotoxic activity on DLD-1 and ECC-1 cancer cells. Waheed et al. [70] noted that phenolic acids (CA and GA) are the most important ingredients of honey with known anti-cancer activity and their main suggested mechanisms are antioxidant, apoptotic, tumour necrosis, anti-inflammatory and estrogenic effects.

\subsection{Effects against Cardiovascular Diseases}

In spite of the medical advances, cardiovascular diseases (CVDs) remain a significant concern, causing the highest number of mortality cases globally and imposing a great burden upon the economies and public health of nations. Research involving both animal and human cells has proven that mixtures of phenolic acids possess cardioprotective properties such as anti-hypertensive, anti-hyperlipidemia and anti-hypertrophy activity [71].

\subsubsection{Individual Phenolic Acids}

Silva and Lopez [72] reviewed the cardiovascular effect of CA and its derivatives. The authors claimed that their antioxidant, anti-inflammatory and anti-angiogenic properties contribute to an important anti-atherosclerotic effect and protect tissues against ischemia/reperfusion injuries and the cellular dysfunction caused by different physicochemical agents. Besides, Olas et al. [73] highlighted the antioxidant and antiplatelet potential of CA, the dietary supplementation of which may ameliorate CVDs through various mechanisms, such as by decreasing oxidative stress and inhibiting blood platelet activation.

Salazar-López et al. [74] supplemented male Wistar rats with either lard at $310 \mathrm{~g} / \mathrm{kg}$ (HFD) or lard and FA at $2 \mathrm{~g} / \mathrm{kg}(\mathrm{HFD}+\mathrm{FA})$ for eight weeks. The rats fed with HFD + FA had significantly lower plasma lipids and glucose levels compared with the HFD group. Bumrungpert et al. [75] conducted a randomized, double-blind, placebo-controlled trial with hyperlipidemia rats. The treatment group $(\mathrm{n}=24)$ was given FA (1000 mg daily) and the control group $(n=24)$ was provided with a placebo for six weeks. FA supplementation demonstrated a statistically significant decrease in total cholesterol $(8.1 \% ; p=0.001)$, LDL-C $(9.3 \% ; p<0.001)$, and triglyceride $(12.1 \% ; p=0.049)$ and increased HDL-C $(4.3 \% ; p=0.045)$ compared with the placebo, while oxidized LDL-C was significantly decreased in the FA group $(7.1 \% ; p=0.002)$. The results of both studies revealed FA's potential to reduce cardiovascular disease risk factors. 
Akbari [76] noted that GA exerts a protective action against CVDs by increasing antioxidant enzyme capacity and inhibition of lipid peroxidation and decreasing serum levels of cardiac marker enzymes.

A study by Ibitoye and Ajiboye [77] investigated the influence of CA, FA and GA on high-fructose diet-induced metabolic syndrome in rats. The authors reported that oral administration of the phenolic acids significantly reversed the increase in the levels of lipid parameters and indices of atherosclerosis, cardiac and cardiovascular diseases.

Sherratt et al. [78] noted that RA and its esters inhibit membrane cholesterol domain formation through an antioxidant mechanism based on alkyl chain length.

\subsubsection{Natural Extracts Rich in Phenolic Acids}

Murino Rafacho et al. [79] reported that daily dietary supplementation (11-110 mg) of rosemary leaves (particularly rich in RA) attenuated cardiac remodelling on male Wistar rats by improving energy metabolism and decreasing oxidative stress. The findings support further investigations of the use of rosemary as an adjuvant therapy against myocardial infarction.

In a study by Faponle et al. [80], 48 adult male rats were supplemented with a leaf extract of Amaranthus spinosus (particularly rich in p-CA) at a single dose of $250 \mathrm{mg} / \mathrm{kg}$ continuously for 28 days. Although no significant alterations were observed in the cholesterol and triglyceride levels of the heart, there was a significant decrease in the atherogenic indices of plasma, revealing a potential protective role against CVD related disorders. Very recently, Fatma et al. [81] reported a clear protective effect of Thymus algeriensis against hydrogen peroxide induced cardiotoxicity in rats.

Panda et al. [82] investigated the cardioprotective activity of the Macrotyloma uniflorum seed extract (MUSE) and its phenolic acids (p-CA and FA) in isoproterenol (ISO)-induced myocardial infarction in rats. Treatment of rats with MUSE ( 250 and $500 \mathrm{mg} / \mathrm{kg}$ ) for 30 days resulted in a significant attenuation of serum marker enzymes, total cholesterol, triglycerides, uric acid and restoration of heart rate, systolic, diastolic and mean arterial pressure.

Cianciosi et al. [83] reviewed the phenolic compounds in honey and their associated health benefits. The authors reported that the abundance of phenolic acids in honey (CA, FA, VA, etc.) may account for its protective effect in the cardiovascular system where it mainly prevents the oxidation of low-density lipoproteins.

\subsection{Effects against Hepatotoxicity and Liver Disorders}

The liver plays a crucial role in the regulation of various physiological processes and in the excretion of endogenous waste metabolites and xenobiotics. The plant kingdom is full of liver protective chemicals such as phenols, carotenoids, flavonoids, and phenolic acids [84].

\subsubsection{Individual Phenolic Acids}

Ajiboye et al. [85] conducted a study to evaluate the influence of CA on 1,3-dichloro-2propanol-induced hepatotoxicity in rats that received distilled water or CA $(10$ or $20 \mathrm{mg} / \mathrm{kg}$ body weight) for seven days. The authors reported that CA protects against 1,3-dichloro-2propanol-induced hepatotoxicity by enhancing the cytoprotective enzymes and lowering inflammation. In addition, $\mathrm{Mu}$ et al. [86] observed that CA protects transplanted livers from injury, which is likely attributed to its protection of oxidative damage by interfering in PDIA3-dependent activation of NADPH oxidase.

Very recently, Hao et al. [87] explored the potential protective effect of CAPE on the cadmium-induced liver damage of 40 male mice that were treated daily with $10 \mu \mathrm{mol}$ $\mathrm{CAPE} / \mathrm{kg}$ body weight, gavage for four weeks. The authors concluded that CAPE administration significantly reduced cadmium level and improved liver tissue histopathology reporting for the first time a CAPE's protection against $\mathrm{CdCl}_{2}$-induced hepatotoxicity.

Chen et al. [88] conducted a dietary supplementation of fish (Megalobrama amblycephala) with FA at 50-100 mg/kg body weight doses. The authors reported that FA significantly 
decreased the contents of pro-inflammatory cytokines such as TNF- $\alpha$ and IL-1 $\beta$, thereby proving that this phenolic acid alleviates lipopolysaccharide-induced acute liver injury in fish.

Owumi et al. [89] studied the effects of GA against hepatoxicity in rats exposed to aflatoxin $\mathrm{B}_{1} \mathrm{AFB}_{1}(75 \mu \mathrm{g} / \mathrm{kg}$ body weight) and treated with GA (20 or $40 \mathrm{mg} / \mathrm{kg}$ ) for 28 successive days. The authors concluded that $\mathrm{GA}$ ameliorated $\mathrm{AFB}_{1}$-induced hepatorenal dysfunction by decreasing oxidative stress and inflammation in rats.

Hussein et al. [90] evaluated the effects of GA and FA against an experimentally induced liver fibrosis by thioacetamide (TAA). Supplementation of rats with both FA and GA at $20 \mathrm{mg} / \mathrm{kg} /$ day, for six weeks exhibited hepatoprotective and antioxidant effects against TAA-induced liver fibrosis (mediated through inhibition of TGF- $\beta 1 /$ Smad3 signalling and differentially regulating the hepatic expression level of miR-21, miR-30 and miR-200).

Lee et al. [91] reported that CarA modulates increased hepatic lipogenesis and adipocyte differentiation in ovariectomized mice fed with normal or high-fat diets.

Oguz et al. [92] exposed 32 rats to hepatic ischaemia/reperfusion (I/R) injury and subsequent treatment with an RA dose of $50 \mathrm{mg} / \mathrm{kg}$ via oral gavage. According to the results, RA significantly reduced liver function test parameters and decreased oxidative stress and abnormal histopathological findings in the liver.

\subsubsection{Natural Extracts Rich in Phenolic Acids}

A few authors have very recently examined the effect of phenolic rich extracts against carbon tetrachloride (CC14)-induced liver injury in mice. Meng et al. [93] have concluded a clear inhibitory activity of $S$. officinalis rich in GA $(8 \mathrm{mg} / \mathrm{g})$. Meharie et al. [94] also reported a similar beneficial effect of Clutia abyssinica (Euphorbiaceae) against mice hepatotoxicity.

In an in vitro study, Hewage et al. [95] evaluated the cytotoxicity and hepatoprotective effect of different solvent fractions (aqua, butanol, chloroform, ethyl acetate and hexane) of S. quelpaertensis Nakai leaf. Between the five fractions $(0-1000 \mu \mathrm{g} / \mathrm{mL})$ only the ethyl acetate fraction, rich in phenolic acids (such as p-CA) showed a hepatoprotective effect against HepG2 cells.

Furthermore, Mbarki et al. [96] reported a clear protective effect of Trigonella foenum graecum (Fenugreek seeds), an extract rich in various phenolic acids, against CC14-induced damage in liver and kidney of male rats.

\subsection{Effects against Neurological Disorders}

\subsubsection{Individual Phenolic Acids}

Alzheimer's disease (AD) is an ultimately fatal brain disorder, which along with other chronic neurodegenerative conditions has imposed an increasingly large burden on social care systems [97]. Various medicinal plants rich in phenolic compounds were reported to exert a beneficial effect in the treatment of AD.

Habtemariam et al. [98] related the anti-AD therapeutic potential of CA with the presence of diorthohydroxyl (catecholic) aromatic moiety and also reviewed the neuroprotective effect of the two most common CA conjugated natural bioactive derivatives (chlorogenic acid and CAPE). Additionally, it was reported that CA improved behavioural impairments, and attenuated loss of dopaminergic neurons in mice, thereby exerting a clear neuroprotective effect [99]. Ferreira et al. [100] assessed the neurotrophic and neuroprotective effects of CAPE against cisplatin-induced neurotoxicity in PC12 cells. The authors reported that CAPE $(10 \mu \mathrm{M})$ attenuated the inhibition of neuritogenesis and the downregulation of markers of neuroplasticity induced by cisplatin $(5 \mu \mathrm{M})$. A recent medical study [101] reported clear inhibitory effects of CAPE against acetylcholinesterase, an enzyme linked with the development of AD.

Bahri et al. [102] noted that CarA can have a protective effect against chronic neurodegenerative conditions, like Parkinson's disease, via a mechanism that links to the transcriptional activation of antioxidant Nrf2/ARE pathway. 
Rehman et al. [103] observed a clear anti-inflammatory effect of FA against LPSinduced neuroinflammation in the mouse brain. Mori et al. [104] supplemented orally transgenic mice with epigallocatechin-3-gallate (EGCG) and/or FA ( $30 \mathrm{mg} / \mathrm{kg}$ each) daily for three months. The authors reported that the combined EGCG-FA treatment reversed cognitive impairment in most tests of learning and memory, presenting thereby an $\mathrm{AD}$ therapeutic effect.

Much attention has been given very recently to the potential beneficial effect of GA on mental health. Shabani et al. [105] reviewed several clinical studies and concluded that GA is effective against nervous system disorders, including $\mathrm{AD}$, Parkinson's disease, ischemia, depression and anxiety. In addition, Liu et al. [106] observed a clear neuroprotective effect of GA following the systemic administration of $100 \mathrm{mg} / \mathrm{kg}$ body weight to neuroinflammatory rat, compared to vehicle-treated rats. Khoshnam et al. [107] reported that GA $(1.0 \mu \mathrm{M})$ protected against neurotoxicity in hippocampal neurons isolated and co-cultured with glial cells.

Rizk et al. [108] reported that oral administration of rats with ellagic acid (10 mg/kg/day) and RA ( $75 \mathrm{mg} / \mathrm{kg} /$ day) for 14 days mitigated the neural changes induced by doxorubicin, a chemotherapeutic agent. Very recently, Salau et al. [109] reported a clear neuroprotective activity of VA against $\mathrm{Fe}^{2+}$-induced oxidative toxicity in brain tissues (neuronal cell lines-HT22). Similarly, VA was found to exert clear neuroprotective effects and restore the spatial memory in rats, following VA supplementation for 14 consecutive days [110].

Table 1. Selection of in vivo and in vitro studies on the health/biochemical properties of various phenolic acids.

\begin{tabular}{|c|c|c|c|}
\hline Health Disease & Phenolic Treatment \& Conditions & Conclusion of Study/Health Effect & References \\
\hline \multirow{3}{*}{$\begin{array}{l}\text { ANTICANCER } \\
\text { PROTECTION }\end{array}$} & $\begin{array}{c}\text { Effect of Thymoquinone (TQ-25 } \mu \mathrm{M}) \text { and FA } \\
(250 \mu \mathrm{M}) \text { on proliferation and apoptosis of a } \\
\text { breast cancer cell line MDA-MB } 231 .\end{array}$ & $\begin{array}{l}\text { FA in combination with TQ significantly } \\
\text { reduced cell proliferation/anticancer effect }\end{array}$ & [55] \\
\hline & $\begin{array}{l}\text { Human EC cells (EC9706 and KYSE450) were } \\
\text { treated with different concentrations } \\
(10-40 \mu \mathrm{g} / \mathrm{mL}) \text { of GA }\end{array}$ & $\begin{array}{c}\text { GA reduced the growth of xenograft tumour } \\
\text { and promoted apoptosis in a concentration } \\
\text { dependent manner. }\end{array}$ & [57] \\
\hline & $\begin{array}{l}\text { Rats subject to DMBA induced oral } \\
\text { carcinogenesis were supplemented with VA } \\
(200 \mathrm{mg} / \mathrm{kg} \text { bw p.o }) \text { for } 14 \text { weeks }\end{array}$ & $\begin{array}{l}\text { VA significantly restored the disturbances in } \\
\text { antioxidants status \{superoxide dismutase, } \\
\text { catalase) to near normal range in DMBA } \\
\text { treated hamsters/anti-cancer effects }\end{array}$ & [62] \\
\hline CARDIO-PROTECTION & $\begin{array}{c}\text { Male Wistar rats supplemented with either lard } \\
\text { at } 310 \mathrm{~g} / \mathrm{kg}(\mathrm{HFD}) \text { or lard and FA at } 2 \mathrm{~g} / \mathrm{kg} \\
\text { (HFD + FA) for } 8 \text { weeks. } \\
\text { Daily dietary supplementation of male Wistar } \\
\text { rats with Rosemary leaves (11-110 mg) rich } \\
\text { in RA }\end{array}$ & $\begin{array}{c}\text { The rats fed with HFD + FA had significantly } \\
\text { lower plasma lipids and glucose levels } \\
\text { compared with the HFD group. } \\
\text { Rosemary attenuated cardiac function } \\
\text { improving metabolism \& decreasing } \\
\text { oxidative stress. }\end{array}$ & {$[79]$} \\
\hline \multirow{4}{*}{ LIVER PROTECTION } & $\begin{array}{l}\text { Activity of CA on } \\
\text { 1,3-dichloro-2-propanol-induced hepatotoxicity } \\
\text { in rats that received CA }(10 \text { or } 20 \mathrm{mg} / \mathrm{kg} \text { bw }) \text { for } \\
7 \text { days. }\end{array}$ & $\begin{array}{l}\text { CA protected against hepatotoxicity by } \\
\text { enhancing the cytoprotective enzymes and } \\
\text { lowering inflammation. }\end{array}$ & [85] \\
\hline & $\begin{array}{l}\text { Dietary supplementation of fish (Megalobrama } \\
\text { amblycephala) with FA at } 50-100 \mathrm{mg} / \mathrm{kg} \mathrm{bw}\end{array}$ & $\begin{array}{l}\text { FA decreased pro-inflammatory cytokines } \\
\text { alleviating acute liver injury. }\end{array}$ & [88] \\
\hline & $\begin{array}{l}\text { Rats exposed to aflatoxin } B_{1} A_{F B}(75 \mu \mathrm{g} / \mathrm{kg} \text { bw }) \\
\text { were treated with GA ( } 20 \text { or } 40 \mathrm{mg} / \mathrm{kg} \text { bw }) \text { for } \\
28 \text { days. }\end{array}$ & $\begin{array}{l}\text { GA ameliorated } \mathrm{AFB}_{1} \text {-induced hepatorenal } \\
\text { dysfunction by decreasing oxidative stress } \\
\text { and inflammation in rats hepatotoxicity. }\end{array}$ & [89] \\
\hline & $\begin{array}{c}32 \text { rats exposed to hepatic } \\
\text { ischaemia/reperfusion injury were subsequently } \\
\text { treated with RA dose of } 50 \mathrm{mg} / \mathrm{kg} \text { via } \\
\text { oral gavage. }\end{array}$ & $\begin{array}{c}\text { RA significantly reduced oxidative stress } \\
\text { and abnormal histopathological findings } \\
\text { in liver. }\end{array}$ & {$[92]$} \\
\hline
\end{tabular}


Table 1. Cont.

\begin{tabular}{|c|c|c|c|}
\hline Health Disease & Phenolic Treatment \& Conditions & Conclusion of Study/Health Effect & References \\
\hline \multirow{4}{*}{ NEURO-PROTECTION } & $\begin{array}{l}\text { Systemic administration of } \\
\text { neuroinflammatory rat with GA } \\
(100 \mathrm{mg} / \mathrm{kg})\end{array}$ & $\begin{array}{l}\text { Clear neuroprotective effect of GA in } \\
\text { treated rats compared to placebo }\end{array}$ & [106] \\
\hline & $\begin{array}{l}\text { Transgenic mice supplemented orally with } \\
\text { epigallocatechin-3-gallate (EGCG) and/or } \\
\text { FA ( } 30 \mathrm{mg} / \mathrm{kg} \text { each) daily for } 3 \mathrm{months} \text { data }\end{array}$ & $\begin{array}{l}\text { The combined EGCG-FA treatment } \\
\text { reversed cognitive impairment, } \\
\text { presenting AD therapeutic effect. }\end{array}$ & [104] \\
\hline & $\begin{array}{c}\text { Dietary supplementation of rats with } \\
500 \mathrm{mg} / \mathrm{kg} \text { body weight) of methanolic } \\
\text { extracts of Salvia splendens (rich in RA and } \\
\text { CA) for } 4 \text { weeks }\end{array}$ & $\begin{array}{l}\text { The treatment significantly attenuated } \\
\mathrm{AlCl}_{3} \text {-induced behavioral impairment } \\
\text { (AD like). }\end{array}$ & [111] \\
\hline & $\begin{array}{c}\text { VA was tested against } \mathrm{Fe}^{2+} \text {-induced } \\
\text { oxidative toxicity in brain tissues (neuronal } \\
\text { cell lines-HT22). }\end{array}$ & $\begin{array}{c}\text { VA exerted a clear } \\
\text { neuroprotective activity. }\end{array}$ & [109] \\
\hline
\end{tabular}

CA: caffeic acid, FA: ferulic acid, GA: gallic acid, RA: rosmarinic acid, VA: vanillic acid, bw: body weight, AD: Alzheimer's disease.

\subsubsection{Natural Extracts Rich in Phenolic Acids}

El-Sawi et al. [111] examined the neuro-therapeutic properties of Salvia splendens plant cultivated in Egypt (particularly rich in RA and CA). The authors reported that dietary supplementation of rats with a dose of $500 \mathrm{mg} / \mathrm{kg}$ body weight of methanolic extracts of Salvia species for 4 weeks significantly attenuated their $\mathrm{AlCl}_{3}$-induced behavioural impairment (similar to that of AD).

During $\mathrm{AD}$, the level of acetylcholine (AChE) in the brain is decreased whereas the level of oxidative reactive species increases and accumulation of $\beta$-amyloid protein starts. A black sesame pigment (extract of black sesame seeds rich in VA) upon simulation by gastrointestinal digestion was reported to have AChE activity [112]. In addition, an antiamyloid aggregation activity of black sesame pigment was noted by Panzella et al. [113], a finding that may offer new perspectives towards its use as a food supplement for the prevention of AD. Liang et al. [114] highlighted the neuroprotective effect of Fagopyrum dibotrys, a natural extract rich in phenolic acids, against AD.

\subsection{Protective Effects against Microbial and Viral Infections (Incl. COVID-19)}

In addition to their antioxidant activities, plant-derived phenolic acids have been reported to exert antimicrobial and anti-inflammatory properties [115]. Over the past few years, herbal extracts and various essential oils rich in phenolics have also shown effective antifungal activities. More specifically, nanohydrogels embedded with natural plant extracts and oils have become the primary choice of pharmaceutical scientists [116]. In addition, a few authors have focused on various botanical sources with antimicrobial properties by exploring their classification, chemical composition and functional properties. Semeniuc et al. [117] examined a range of botanical essential oils (parsley, lovage, basil, thyme) using various chemometric methods and concluded that thyme essential oil exhibited the stronger antibacterial activity. An overview of the most recent studies on the potential activity of phenolic acids against microbial relevant infections is given in Table 2 .

\subsubsection{Antimicrobial Activity of Phenolic Acids-Mechanism of Action}

Liu et al. [118] noted that the chemical structure of phenolic acids enables their potential incorporation into biomaterial scaffolds, thus providing naturally derived functionalities that could improve healing outcomes. The chemical structure, position and number of substitutions in benzene rings seem to determine the anti-microbial activity of phenolic acids [119]. An increase in alkyl chain lengths enhances activity while hydroxybenzoic and hydroxycinnamic acids show different modes of action depending on the number of hydroxy and methoxy functional groups [120].

Wu et al. [121] reviewed the activity of various naturally derived phenolic acids with diverse skeletons and mechanisms, and concluded that CA and GA and their derivatives, 
especially, could provide us with an excellent source of novel antiviral drugs. Paulo and Santos [122] examined how incorporation of caffeic-ethyl cellulose microparticles in skin care products can offer antimicrobial and anti-aging protection. Moreover, Langland et al. [123] has reported an antiviral activity of CA towards herpes simplex (HSV), VSV-Ebola pseudotyped and vaccinia viruses. The authors reported that the antiviral activity increased and occurred early in the virus replication cycle with the addition of chelated inorganic ions or a metal such as iron to CA. Zhang et al. [124] observed that the cocktail of either CA $(1.5 \mathrm{mg} / \mathrm{mL})$ or chlorogenic acid $(3 \mathrm{mg} / \mathrm{mL})$ with the antibiotic fosfomycin $(50 \mathrm{mg} / \mathrm{L})$ was able to significantly inhibit the growth of the pathogen Listeria monocytogenes.

De Camargo et al. [125] reported that phenolic acid-rich extracts from peanut sources (24-49 $\mu$ g phenolics/mL) exhibited a high antibacterial effect against the growth of Grampositive (Bacillus cereus, Staphylococcus aureus, Listeria monocytogenes, etc.) and Gramnegative bacteria (Pseudomonas aeruginosa, Salmonella Enteritidis, Escherichia coli, etc.).

Baidoo et al. [126] investigated the wound healing, antimicrobial and anti-oxidant activities of methanol extracts of the leaf and stem of E. africana tested in the dermal excision wound model in rats. The methanol extract of bark stem, having GA as the main phenolic compound, demonstrated antibacterial activity against Staphylococcus aureus and Streptococcus pyogenes with a minimum inhibitory concentration of $1.56 \mathrm{mg} / \mathrm{mL}$ and thereby a great potential for the treatment of open wounds.

\subsubsection{Potential Protective Effects of Phenolic Acids against Coronavirus-Based Infections}

Coronaviruses are the causative agents of many infectious diseases in humans and animals. These included severe acute respiratory syndrome (SARS), avian infectious bronchitis (IBV) in poultry, Middle East respiratory syndrome (MERS), and coronavirus disease 2019 (COVID-19) in humans [127]. The majority of publications on the herbal remedies of coronavirus, MERS, or SARS focused primarily on the use of polar compounds, including phenolic acids (namely CA) and flavonoids (namely quercetin and myricetin) [128].

Upon viral infection, heat shock protein A5 (HSPA5) is upregulated, then translocated to the cell membrane where it can recognize the SARS-CoV-2 spike. Elfiky et al. [129], using molecular docking and molecular dynamics, tested a few natural product compounds against the HSPA5 substrate-binding domain $\beta(\mathrm{SBD} \beta)$. The results show a high to moderate binding affinity for a range of phenolic acids. More specifically, CA, CAPE, and p-CA may bind to cell-surface HSPA5, competing for its recognition by viral spike protein and contradicting its attachment. These compounds can be successful as anti-COVID-19 agents for people with a high risk of cell stress, like elders, cancer patients, and front-line medical staff. Similarly, Kumar et al. [130] used the strengths of molecular dynamics simulations and concluded that since the natural phenolic compounds are easily available/affordable, they may even offer a timely therapeutic/preventive value for the management of the SARS-CoV-2 pandemic.

Khalil and Tazeddinova [131] concluded that CA and GA could be considered in the treatment of COVID-19 and its related symptoms. Moreover, GA and CA were found to exert sustainable anti-viral activity against human coronavirus NL63 (HCoV-NL63), one of the main circulating coronaviruses worldwide that causes respiratory tract diseases like runny nose, cough, bronchiolitis and pneumonia [132]. 
Table 2. Overview of the most recent studies on the potential activity of phenolic acids against microbial and viral relevant infections, including SARS-CoV-2.

\begin{tabular}{|c|c|c|}
\hline Phenolic Acid Treatment & $\begin{array}{c}\text { Activity against } \\
\text { Microorganism/Infections }\end{array}$ & References \\
\hline $\begin{array}{c}\text { CA enhanced with chelated } \\
\text { inorganic ions (or a metal } \\
\text { such as iron) }\end{array}$ & $\begin{array}{l}\text { Antiviral activity towards } \\
\text { herpes simplex (HSV), } \\
\text { VSV-Ebola pseudotypes and } \\
\text { vaccinia viruses occurred } \\
\text { early in the virus replication } \\
\text { cycle. }\end{array}$ & [123] \\
\hline $\begin{array}{c}\mathrm{CA}(1.5 \mathrm{mg} / \mathrm{mL}) \text { and } \\
\text { chlorogenic acid }(3 \mathrm{mg} / \mathrm{mL})\end{array}$ & $\begin{array}{c}\text { Phenolic cocktail significantly } \\
\text { inhibit the growth of the food } \\
\text { born pathogen Listeria } \\
\text { monocytogenes. }\end{array}$ & [99] \\
\hline $\begin{array}{c}\text { Methanol extracts of the leaf } \\
\text { and stem of E. africana (rich in } \\
\text { GA) }\end{array}$ & $\begin{array}{c}\text { Antioxidant and antibacterial } \\
\text { activity against Staphylococcus } \\
\text { (S. aureus and S. pyogenes) } \\
\text { with a minimum inhibitory } \\
\text { concentration of } \\
1.56 \mathrm{mg} / \mathrm{mL} \text {-great potential } \\
\text { for treatment of open wounds }\end{array}$ & [126] \\
\hline $\mathrm{CA}$ and $\mathrm{GA}$ & $\begin{array}{l}\text { CA and GA were found to } \\
\text { exert good anti-viral activity } \\
\text { against human coronavirus } \\
\text { NL63 (HCoV-NL63) }\end{array}$ & [132] \\
\hline $\mathrm{CA}$ and $\mathrm{p}-\mathrm{CA}$ & $\begin{array}{l}\text { Phenolic acids were found to } \\
\text { bind to cell-surface HSPA5 } \\
\text { competing for recognition by } \\
\text { SARS-CoV-2 spike protein }\end{array}$ & [129] \\
\hline $\begin{array}{c}\text { Screening of } 27 \mathrm{CA} \\
\text { derivatives against } 5 \text { proteins } \\
\text { of SARS-CoV-2 }\end{array}$ & $\begin{array}{l}5 \text { CA derivatives exerted } \\
\text { anti-viral efficacy against } \\
\text { COVID-19 via molecular } \\
\text { docking and molecular } \\
\text { dynamics simulation. }\end{array}$ & [133] \\
\hline
\end{tabular}

CA: caffeic acid, GA: gallic acid, $p$-CA: coumaric acid.

Adem et al. [133] screened 27 CA derivatives against five proteins of SARS-CoV-2 aiming to evaluate the anti-viral efficacy of these natural bioactive entities against COVID-19 via molecular docking and molecular dynamics simulation. The obtained results have uncovered khainaoside C, 6-O-Caffeoylarbutin, khainaoside B, khainaoside $\mathrm{C}$ and vitexfolin A as potent modulators of COVID-19, possessing more binding energies than nelfinavir against COVID-19. Very recently, rosmarinic acid was claimed to have a demonstrated potential to increase the activity or expression of ACE-2 and could therefore aggravate SARS-CoV-2 effects [134].

\section{Conclusions and Prospects}

Based on this analysis of the in vitro and in vivo biochemical activities of phenolic acids, the authors have drawn the following conclusions:

A number of recent in vivo animal clinical trials and in vitro human cell studies offered sufficient evidence to support that the examined phenolic acids possess health protective effects against several pathogenic conditions, including cancer, cardiovascular, liver, and neurodegenerative diseases, as well as microbial infections. Based on their strong antiviral activities, phenolic acids could also be considered in the development of medical treatments against the spread of COVID-19 and its related symptoms.

Concerning the mechanism of actions we can note that: (a) the phenolic acid activity against types of cancer and cardiovascular diseases may respectively link to their estab- 
lished antioxidant effect against DNA damage and LDL oxidative deterioration; (b) the antimicrobial activity of phenolic acids is well determined by their structure and presence of functional groups (with CA and GA exerting the strongest reported activities) -although phenolic acids have shown clear neuro-protective effects, their exact mode of activity against neurotoxicity needs some further elucidation before further clinical developments; and (c) a number of botanical extracts rich in various phenolic acids have been increasingly shown to exert strong antioxidant and biochemical properties, a fact that may be associated with the synergistic effects of their individual phenolic compounds.

About future prospects in this scientific field, the authors would like to note that: (i) although the pharmacokinetic and non-toxic profile of phenolic acids make them suitable for clinical studies, in vivo human trials are needed to further explore their potential for extensive pharmaceutical applications; and (ii) since a number of recent model studies came out with promising results about the therapeutic potential of phenolic acid-based drugs for treatment or prevention of COVID-19, further in vitro and in vivo studies should be performed to clarify and evaluate the specific antiviral effects of these phytochemicals.

Author Contributions: Conceptualization, S.K. and V.O.; resources, S.K. and V.O.; writing-original draft preparation, S.K.; writing - review and editing, S.K. and V.O.; supervision, V.O. Both authors have contributed substantially to the work reported. The views expressed in this publication are purely those of the writers and may not in any circumstances be regarded as stating an official position of the European Commission. All authors have read and agreed to the published version of the manuscript.

Funding: This research received no external funding.

Institutional Review Board Statement: Not applicable.

Informed Consent Statement: Not applicable.

Data Availability Statement: Not applicable.

Conflicts of Interest: The authors declare no conflict of interest.

$\begin{array}{ll}\text { Abbreviations } \\ \text { AChE } & \text { acetylcholine } \\ \text { AD } & \text { Alzheimer's disease } \\ \text { CA } & \text { caffeic acid } \\ \text { CAPE } & \text { caffeic acid phenethyl ester } \\ \text { CarA } & \text { carnocic acid } \\ \text { CC14 } & \text { carbon tetrachloride } \\ \text { COVID-19 } & \text { coronavirus disease 2019 } \\ \text { CVDs } & \text { cardiovascular diseases } \\ \text { DMBA } & \text { dimethylbenz[a]anthracene } \\ \text { DNA } & \text { deoxyribonucleic acid } \\ \text { EGCG } & \text { epigallocatechin-3-gallate } \\ \text { FA } & \text { ferulic acid } \\ \text { GA } & \text { gallic acid } \\ \text { HDL } & \text { high density lipoproteins } \\ \text { HPLC } & \text { high performance liquid chromatography } \\ \text { HSPA5 } & \text { heat shock protein A5 } \\ \text { LDL } & \text { low density lipoproteins } \\ \text { p-CA-p } & \text { coumaric acid } \\ \text { RA } & \text { rosmarinic acid } \\ \text { ROS } & \text { reactive active oxygen species } \\ \text { SARS } & \text { severe acute respiratory syndrome } \\ \text { TAA } & \text { thioacetamide } \\ \text { VA } & \text { vanillic Acid } \\ & \end{array}$




\section{References}

1. Lobo, V.; Patil, A.; Phatak, A.; Chandra, N. Free radicals, antioxidants and functional foods: Impact on human health. Pharmacogen. Rev. 2010, 4, 118-126. [CrossRef]

2. Yan, M.; Lo, C.-J.; Edwards, T.-J.; Baran, S.-P. Radicals: Reactive intermediates with translational potential. J. Am. Chem. Soc. 2016, 138, 12692-12714. [CrossRef]

3. Dizdaroglu, M.; Jaruga, P. Mechanisms of free radical-induced damage to DNA. Free Radic. Res. 2012, 46, 382-419. [CrossRef] [PubMed]

4. Mamede, A.C.; Tavares, S.D.; Abrantes, A.M.; Trindade, J.; Maia, J.M.; Botelho, M.F. The role of vitamins in cancer: A review. Nutr. Cancer 2011, 63, 479-494. [CrossRef] [PubMed]

5. Kiokias, S.; Proestos, C.; Oreopoulou, V. Effect of natural Food Antioxidants against LDL and DNA Oxidative damages. Antioxidants 2018, 7, 133. [CrossRef] [PubMed]

6. Kiokias, S.; Proestos, C.; Oreopoulou, V. Beneficial Health Properties of Common Natural Phenolic Acids. Encyclopedia. 2020. Available online: https:/ / encyclopedia.pub/1205 (accessed on 13 January 2021).

7. Yemiş, G.P.; Pagotto, F.; Bach, S.; Delaquis, P. Effect of Vanillin, Ethyl Vanillin, and Vanillic Acid on the Growth and Heat Resistance of Cronobacter Species. J. Food Protect. 2011, 74, 2062-2069. [CrossRef] [PubMed]

8. Jungbauer, A.; Medjakovic, S. Anti-inflammatory properties of culinary herbs and spices that ameliorate the effects of metabolic syndrome. Maturitas 2012, 71, 227-239. [CrossRef]

9. Kiokias, S. Antioxidant effects of vitamins C, E and provitamin A compounds as monitored by use of biochemical oxidative indicators linked to atherosclerosis and carcinogenesis. Intern. J. Nutr. Res. 2019, 1, 1-13.

10. Manuja, R.; Sachdeva, S.; Jain, A.; Chaudhary, J. A comprehensive review on biological activities of p-hydroxy benzoic acid and its derivatives. Int. J. Pharm. Sci. Rev. Res. 2013, 22, 109-115.

11. Kiokias, S.; Proestos, C.; Oreopoulou, V. Phenolic acids of plant origin-A review on their antioxidant activity in vitro (o/w emulsion systems) along with their in vivo health biochemical properties. Foods 2020, 9, 534. [CrossRef]

12. Liu, Y.; Carver, J.A.; Calabrese, A.N.; Pukala, T.L. Gallic acid interacts with $\alpha$-synuclein to prevent the structural collapse necessary for its aggregation. Biochim. Biophys. Acta (BBA)-Prot. Proteom. 2014, 1844, 1481-1485. [CrossRef]

13. Tsimogiannis, D.; Oreopoulou, V. Classification of phenolic compounds in Plants. In Polyphenols in Plants Isolation Purification and Extract Preparation, 2nd ed.; Watson, R.R., Ed.; Elsevier Inc.: London, UK, 2019; pp. 263-284.

14. Dalbem, L.; Costa Monteiro, C.M.; Anderson, J.T. Anticancer properties of hydroxycinnamic acids-A Review. Canc. Clin. Oncol. 2012, 1, 109-121.

15. Cabras, P.; Angioni, A.; Tuberoso, C.; Floris, I.; Reniero, F.; Guillou, C.; Ghelli, S. Homogentisic acid: A phenolic acid as a marker of strawberry-tree (Arbutus unedo) honey. J. Agric. Food Chem. 1999, 47, 4064-4067. [CrossRef]

16. Berté, K.A.; Beux, M.R.; Spada, P.K.; Salvador, M.; Hoffmann-Ribani, R. Chemical composition and antioxidant activity of yerba-mate (Ilex paraguariensis A.St.-Hil., Aquifoliaceae) extract as obtained by spray drying. J. Agric. Food Chem 2011, 25, 5523-5527. [CrossRef]

17. Sugahara, S.; Chiyo, A.; Fukuoka, K.; Ueda, Y.; Tokunaga, Y.; Nishida, Y.; Kinoshita, H.; Matsuda, Y.; Igoshi, K.; Ono, M.; et al. Unique antioxidant effects of herbal leaf tea and stem tea from Moringa oleifera L. especially on superoxide anion radical generation systems. Biosci. Biotechnol. Biochem. 2018, 82, 1973-1984. [CrossRef]

18. Žugić, A.; Đorđević, S.; Arsić, I.; Marković, G.; Živković, J.; Jovanovic, S.; Tadić, V. Antioxidant activity and phenolic compounds in 10 selected herbs from Vrujci Spa, Serbia. Indust. Crops Prod. 2014, 52, 519-527. [CrossRef]

19. Loussouarn, M.; Krieger-Liszkay, A.; Svilar, L.; Bily, A.; Birtić, S.; Havaux, M. Carnosic Acid and Carnosol, Two Major Antioxidants of Rosemary, Act through Different Mechanisms. Plant Physiol. 2017, 175, 1381-1394. [CrossRef] [PubMed]

20. Raes, K.; Doolaege, E.H.A.; Deman, S.; Vossen, E.; De Smet, S. Effect of carnosic acid, quercetin and $\alpha$-tocopherol on lipid and protein oxidation in anin vitrosimulated gastric digestion model. Intern. J. Food Sci. Nutr. 2015, 66, 216-221. [CrossRef]

21. Flanagan, J.; Bily, A.; Rolland, Y.; Roller, M. Lipolytic Activity of Svetol ${ }^{\circledR}$, a Decaffeinated Green Coffee Bean Extract. Phytoth. Res. 2013, 28, 946-948. [CrossRef] [PubMed]

22. Mojica, L.; Meyer, A.; Berhow, M.; González, E. Bean cultivars (Phaseolus vulgaris L.) have similar high antioxidant capacity, in vitro inhibition of $\alpha$-amylase and $\alpha$-glucosidase while diverse phenolic composition and concentration. Food Res. Intern. 2015, 69, 38-48. [CrossRef]

23. Wei, W.L.; Zeng, R.; Gu, C.M.; Qu, Y.; Huang, L.F. Angelica sinensis in China-A review of botanical profile, ethnopharmacology, phytochemistry and chemical analysis. J. Ethnopharmacol. 2016, 190, 116-141. [CrossRef]

24. Pandurangan, A.K.; Mohebali, N.; Norhaizan, M.E.; Looi, C.Y. Gallic acid attenuates dextran sulfate sodium-induced experimental colitis in BALB/c mice. Drug Des. Dev. Ther. 2015, 9, 3923-3934. [CrossRef]

25. Zucca, P.; Rosa, A.; Tuberoso, C.; Piras, A.; Rinaldi, A.C.; Sanjust, E.; Dessi, A.; Rescigno, A. Evaluation of Antioxidant Potential of "Maltese Mushroom" (Cynomorium coccineum) by Means of Multiple Chemical and Biological Assays. Nutrients 2013, 5, 149-161. [CrossRef]

26. Rangani, I.; Kumari, A.; Patel, M.; Brahmbhatt, H.; Parida, A.K. Phytochemical profiling, polyphenol composition, and antioxidant activity of the leaf extract from the medicinal halophyte Thespesia populnea reveal a potential source of bioactive compounds and nutraceuticals. J. Food Biochem. 2019, 43, e12731. [CrossRef] [PubMed] 
27. Trisha, S. Role of hesperdin, luteolin and coumaric acid in arthritis management: A Review. Int. J. Phys. Nutr. Phys. Educ. 2018, 3, 1183-1186.

28. Kavita, P.; Gandhi, P. Rediscovering the therapeutic potential of Amaranthus species: A review. Egypt J. Basic Appl. Sci. 2017, 4, 196-205. [CrossRef]

29. Woogyeong, K.; Dahae, L.; Jinju, K. p-Coumaric Acid, a Major Active Compound of Bambusae Caulis in Taeniam, Suppresses Cigarette Smoke-Induced Pulmonary Inflammation. Am. J. Chin. Med. 2018, 46, 407-421. [CrossRef]

30. Multari, S.; Pihlava, J.M.; Ollennu-Chuasam, P.; Hietaniemi, V.; Yang, B.; Suomela, J.P. Identification and Quantification of Avenanthramides and Free and Bound Phenolic Acids in Eight Cultivars of Husked Oat (Avena sativa L) from Finland. J. Agric. Food Chem. 2018, 68, 2900-2908. [CrossRef]

31. Yashin, A.; Yashin, Y.; Xia, X.; Nemzer, V. Antioxidant Activity of Spices and Their Impact on Human Health: A Review. Antioxidants 2017, 6, 70. [CrossRef]

32. Tsimogiannis, D.; Choulitoudi, E.; Bimpilas, A.; Mitropoulou, G.; Kourkoutas, Y.; Oreopoulou, V. Exploitation of the biological potential of Satureja thymbra essential oil and distillation by-products. J. Appl. Res. Med. Aromat. Plants 2016, 4, 12-20. [CrossRef]

33. Pacheco-Palencia, L.A.; Mertens, T.S.; Talcott, S.-T. Chemical composition, antioxidant properties, and thermal stability of a phytochemical enriched oil from Acai (Euterpe oleracea Mart.). J. Agric. Food Chem. 2008, 56, 4631-4636. [CrossRef]

34. Chengke, Z.; Yuan, J.; Fachuang, L. Angelica Stem: A Potential Low-Cost Source of Bioactive Phthalides and Phytosterols. Molecules 2018, 23, 3065. [CrossRef]

35. Oreopoulou, A.; Tsimogiannis, D.; Oreopoulou, V. Extraction of Polyphenols From Aromatic and Medicinal Plants: An Overview of the Methods and the Effect of Extraction Parameters. In Polyphenols in Plants Isolation Purification and Extract Preparation, 2nd ed.; Watson, R.R., Ed.; Elsevier Inc.: London, UK, 2019; pp. 243-260.

36. Psarrou, I.; Oreopoulou, A.; Tsimogiannis, D.; Oreopoulou, V. Extraction Kinetics of Phenolic Antioxidants from the Hydro Distillation Residues of Rosemary and Effect of Pretreatment and Extraction Parameters. Molecules 2020, 25, 4520. [CrossRef]

37. Oreopoulou, A.; Goussias, G.; Tsimogiannis, D.; Oreopoulou, V. Hydro-alcoholic Extraction Kinetics of Phenolics from Oregano: Optimization of the Extraction Parameters. Food Bioprod. Proc. 2020, 123, 378-389. [CrossRef]

38. Corbin, C.; Fidel, T.; Leclerc, E.A.; Barakzoy, E.; Sagot, N.; Falguiéres, A.; Lainé, E. Development and validation of an efficient ultrasound assisted extraction of phenolic compounds from flax (Linum usitatissimum L.) seeds. Ultras. Sonochem. 2015, 26, 176-185. [CrossRef]

39. De AR Oliveira, G.; De Oliveira, A.E.; Da Conceição, E.C.; Leles, M.I. Multiresponse optimization of an extraction procedure of carnosol and rosmarinic and carnosic acids from rosemary. Food Chem. 2016, 211, 465-473. [CrossRef] [PubMed]

40. Max, B.; Salgado, J.M.; Cortés, S.; Domínguez, J.M. Extraction of phenolic acids by alkaline hydrolysis from the solid residue obtained after prehydrolysis of trimming vine shoots. J. Agric. Food Chem. 2009, 58, 1909-1917. [CrossRef]

41. Gonzales, G.B.; Raes, K.; Vanhoutte, H.; Coelus, S.; Smagghe, G.; Van Camp, J. Liquid chromatography-mass spectrometry coupled with multivariate analysis for the characterization and discrimination of extractable and nonextractable polyphenols and glucosinolates from red cabbage and Brussels sprout waste streams. J. Chrom. A 2015, 1402, 60-70. [CrossRef]

42. Kumar, N.; Goel, N. Phenolic acids: Natural versatile molecules with promising therapeutic applications. Biotechnol. Rep. 2019, 24, e00370. [CrossRef]

43. Kehan, P.; Ou, J.; Huanga, J.; Oua, S. Coumaric acid and itsconjugates: Dietary sources, pharmacokinetic properties and biological activities. J. Sci. Food Agric. 2016, 96, 2952-2962. [CrossRef]

44. Proestos, C.; Komaitis, M. Application of microwave-assisted extraction to the fast extraction of plant phenolic compounds. LWT-Food Sci. Technol. 2008, 41, 652-659. [CrossRef]

45. Bernatoniene, J.; Cizauskaite, U.; Ivanauskas, L.; Jakstas, V.; Kalveniene, Z.; Kopustinskiene, D.M. Novel approaches to optimize extraction processes of ursolic, oleanolic and rosmarinic acids from Rosmarinus officinalis leaves. Ind. Crops Prod. 2016, 84, 72-79. [CrossRef]

46. Ciulu, M.; de la Luz Cádiz-Gurrea, M.; Segura-Carretero, A. Extraction and Analysis of Phenolic Compounds in Rice: A Review. Molecules 2018, 23, 2890. [CrossRef]

47. Pyrzynska, K.; Sentkowska, A. Chromatographic Analysis of Polyphenols. In Polyphenols in Plants Isolation Purification and Extract Preparation, 2nd ed.; Watson, R.R., Ed.; Elsevier Inc.: London, UK, 2019; pp. 353-364.

48. Vinas, P.; Campillo, N. Gas Chromatography: Mass Spectrometry Analysis of Polyphenols in Foods. In Polyphenols in Plants Isolation Purification and Extract Preparation, 2nd ed.; Watson, R.R., Ed.; Elsevier Inc.: London, UK, 2019; pp. $285-316$.

49. Kiokias, S.; Varzakas, T. Activity of flavonoids and beta-carotene during the auto-oxidative deterioration of model food oil-in water emulsions. Food Chem. 2014, 150, 280-286. [CrossRef]

50. Nourah, A.; Al Zahrani, N.A.; El-Shishtawy, R.M.; Asiri, A.M. Recent developments of gallic acid derivatives and their hybrids in medicinal chemistry: A review. Eur. J. Med. Chem. 2020, 204, 112609. [CrossRef]

51. Abotaleb, M.; Liskova, A.; Kubatka, P.; Büsselberg, D. Therapeutic Potential of Plant Phenolic Acids in the Treatment of Cancer. Biomolecules 2020, 10, 221. [CrossRef]

52. Gaglione, M.; Malgieri, G.; Pacifico, S.; Severino, V.; D’Abrosca, P.; Russo, L.; Fiorentino, A.; Messere, A. Synthesis and Biological Properties of Caffeic Acid-PNA Dimers Containing Guanine. Molecules 2013, 18, 9147-9162. [CrossRef]

53. Wang, J.; Bhargava, P.; Yu, Y.; Sari, A.N.; Zhang, H.; Ishii, N. Novel Caffeic Acid Phenethyl Ester-Mortalin Antibody Nanoparticles Offer Enhanced Selective Cytotoxicity to Cancer Cells. Cancers 2020, 12, 2370. [CrossRef] 
54. Zhang, A.; Lin, A.; Jiang, R.; Li, H.; Wan, H. Ferulic acid exerts antitumour activity and inhibits metastasis in breast cancer cells by regulating epithelial to mesenchymal transition. Oncol. Rep. 2016, 36, 271-278. [CrossRef]

55. Al-Mutairi, A.; Rahman, A.; Rao, M.S. Low Doses of Thymoquinone and Ferulic Acid in Combination Effectively Inhibit Proliferation of Cultured MDA-MB 231 Breast Adenocarcinoma Cells. Nutr. Cancer 2020, 72, 8. [CrossRef] [PubMed]

56. Solomonov, Y.; Hadad, N.; Levy, R. The combined anti-inflammatory effect of astaxanthin, lyc-O-mato and carnosic acid in vitro and in vivo in a mouse model of peritonitis. J. Nutr. Food Sci. 2018, 8, 653. [CrossRef]

57. Sun, G.L.; Wang, D. Gallic acid from Terminalia chebula inhibited the growth of esophageal carcinoma cells by suppressing the Hippo signal pathway. Iran. J. Basic Med. Sci. 2020, 23, 1401-1408. [CrossRef] [PubMed]

58. Sales, M.S.; Roy, A.; Antony, L.; Banu, S.K.; Jeyaraman, S.; Manikkam, R. Octyl gallate and gallic acid isolated from Terminalia bellarica regulates normal cell cycle in human breast cancer cell lines. Biomed. Pharmacother. 2018, 103, 1577-1584. [CrossRef]

59. Afonso, F.A.; Pereira, O.R.; Cardoso, S.M. Health-Promoting Effects of Thymus Phenolic-Rich Extracts: Antioxidant, AntiInflammatory and Antitumoural Properties. Antioxidants 2020, 9, 814. [CrossRef]

60. Luo, Y.; Ma, Z.; Xu, X.; Qi, H.; Cheng, Z.; Chen, L. Anticancer effects of Rosmarinic acid in human oral cancee cells is mediated via endoplasmic reticulum stress, apoptosis, G2/M cell cycle arrest and inhibition of cell migration. J. BUON 2020, 25, 1245-1250. [PubMed]

61. Messeha, S.S.; Zarmouh, N.O.; Asiri, A.; Soliman, K.F.A. Rosmarinic acid-induced apoptosis and cell cycle arrest in triple-negative breast cancer cells. Eur. J. Pharmacol. 2020, 885, 173419. [CrossRef]

62. Anbalagan, V.; Raju, K.; Shanmugam, K. Assessment of Lipid Peroxidation and Antioxidant Status in Vanillic Acid Treated 7,12-Dimethylbenz[a]anthracene Induced Hamster Buccal Pouch Carcinogenesis. J. Clin. Diagn. Res. 2017, 11, BF01. [CrossRef]

63. Gong, J.; Zhou, S.; Yang, S. Vanillic Acid Suppresses HIF-1 $\alpha$ Expression via Inhibition of mTOR/p70S6K/4E-BP1 and Raf/MEK/ERK Pathways in Human Colon Cancer HCT116 Cells. Int. J. Mol. Sci. 2019, 22, 465. [CrossRef]

64. Taner, G.; Ozkan Vardar, D.; Aydin, S.; Aytac, Z.; Basaran, A.; Basaran, N. Use of in vitro assays to assess the potential cytotoxic, genotoxic and antigenotoxic effects of vanillic and cinnamic acid. Drug Chem. Toxicol. 2017, 40, 183-190. [CrossRef]

65. Jeong, N.; Phan, H.; Jong-Whan, C. Anti-cancer effects of polyphenolic compounds in epidermal growth factor receptor tyrosine kinase inhibitor-resistant non-small cell lung cancer. Pharmacogn. Mag. 2017, 13, 595-599. [CrossRef]

66. Trivellini, A.; Lucchesini, M.; Maggini, R.; Mosadegh, H.; Villamarin, T.-S.; Vernieri, P.; Mensuali-Sodi, A.; Pardossi, A. Lamiaceae phenols as multifaceted compounds: Bioactivity, industrial prospects and role of "positive-stress". Industr. Crops Product. 2016, 83, 241-254. [CrossRef]

67. Oreopoulou, A.; Papavassilopoulou, E.; Bardouki, H.; Vamvakias, M.; Bimpilas, A.; Oreopoulou, V. Antioxidant recovery from hydrodistillation residues of selected Lamiaceae species by alkaline extraction. J. Appl. Res. Medic. Aromat. Plants 2018, 8, 83-89. [CrossRef]

68. Fernandes, A.; Mazzei, H.J.; Evangelista, H.; Da Costa Marques Calderari, M.J.; Ferraz, E.R.A.; Felzenszwalb, I. Protection against UV-induced oxidative stress and DNA damage by Amazon moss extracts. J. Photoch. Photob. B Biol. 2018, 183, 331-341. [CrossRef] [PubMed]

69. Koyuncu, I.; Gönel, A.; Akdağ, A.; Yilmaz, M.A. Identification of phenolic compounds, antioxidant activity and anti-cancer effects of the extract obtained from the shoots of Ornithogalum narbonense L. Cell Mol. Biol. 2018, 64, 75-83. [CrossRef] [PubMed]

70. Waheed, M.; Hussain, M.B.; Javed, A.; Mushtaq, Z.; Hassan, S.; Sariati, M.-A.; Khan, M.-U.; Majeed, M.; Nigam, M.; Mishra, A.-P.; et al. Honey and cancer: A mechanistic review. Clin. Nutr. 2019, 38, 2499-2503. [CrossRef]

71. Ali, S.S.; Ahmad, W.A.; Budin, S.B.; Zainalabidin, S. Implication of dietary phenolic acids on inflammation in cardiovascular disease. Rev. Cardiovasc. Med. 2020, 21, 225-240. [CrossRef] [PubMed]

72. Silva, H.; Lopes., N.M. Cardiovascular Effects of Caffeic Acid and Its Derivatives: A Comprehensive Review. Front. Physiol. 2020, 27, 595516. [CrossRef]

73. Olas, B. Honey and its phenolic compounds as an effective natural medicine for cardiovascular diseases in humans? Nutrients 2020, 12, 283. [CrossRef]

74. Salazar-López, N.Z.; Astiazarán-García, H.; González-Aguilar, A.; Loarca-Piña, G.; Ezquerra-Brauer, J.M.; Domínguez Avila, J.A.; Robles-Sánchez, M. Ferulic Acid on Glucose Dysregulation, Dyslipidemia, and Inflammation in Diet-Induced Obese Rats: An Integrated Study. Nutrients 2017, 29, 675. [CrossRef] [PubMed]

75. Bumrungpert, A.; Lilitchan, S.; Tuntipopipat, S.; Tirawanchai, N.; Komindr, S. Ferulic Acid Supplementation Improves Lipid Profiles, Oxidative Stress, and Inflammatory Status in Hyperlipidemic Subjects: A Randomized, Double-Blind, Placebo-Controlled Clinical Trial. Nutrients 2018, 10, 713. [CrossRef] [PubMed]

76. Akbari, G. Molecular mechanisms underlying gallic acid effects against cardiovascular diseases: An update review. J. Phytomed. 2020, 10, 11-23.

77. Ibitoye, O.B.; Ajiboy, O.T. Dietary phenolic acids reverse insulin resistance, hyperglycaemia, dyslipidaemia, inflammation and oxidative stress in high-fructose diet-induced metabolic syndrome rats. Arch. Physiol. Biochem. 2018, 124, 410-417. [CrossRef] [PubMed]

78. Sherratt, S.C.R.; Villeneuve, P.; Durand, E.; Mason, R.P. Rosmarinic acid and its esters inhibit membrane cholesterol domain formation through an antioxidant mechanism based, in nonlinear fashion, on alkyl chain length. Biochim. Biophys. Acta Biomembr. 2019, 1861, 550-555. [CrossRef] [PubMed] 
79. Murino Rafacho, B.P.; Dos Santos, P.P.; Gonçalves, A.; Henrique Fernandes, A.A.; Okoshi, K.; Chiuso-Minicucci, F.; Azevedo, P.S.; Zornoff, L.A.M.; Minicucci, M.F.; Wang, X.-D.; et al. Rosemary supplementation (Rosmarinus ofici nallis L.) attenuates cardiac remodeling after myocardial infarction in rats. PLOS ONE 2017, 12, e0177521. [CrossRef]

80. Faponle, A.S.; Atunnise, A.K.; Adegbesan, B.O. Separate and co-administration of Amaranthus spinosus and vitamin C modulates cardiovascular disease risk in high fat diet-fed experimental rats. J. Pharmac. Phytoth. 2015, 7, 27-34. [CrossRef]

81. Fatma, G.; Khantouche, L.; Amel, M.; Bellamine, H.; Landoulsi, A. Histopathological and Biochemical Effects of Thyme Essential Oil on $\mathrm{H}_{2} \mathrm{O}_{2}$ Stress in Heart Tissues. Heart Lung Circ. 2020, 29, 308-314. [CrossRef]

82. Panda, V.; Laddha, A.; Nandave, M.; Srinath, S. Dietary Phenolic Acids of Macrotyloma uniflorum (Horse Gram) Protect the Rat Heart against Isoproterenol-Induced Myocardial Infarction. Phytother. Res. 2016, 30, 1146-1155. [CrossRef]

83. Cianciosi, D.; Forbes-Hernández, T.W.; Afrin, S.; Gasparrini, M.; Reboredo-Rodriguez, P.; Reboredo-Rodriguez, P.; Pia Manna, P.; Zhang, J.; Bravo Lamas, L.; Martínez Flórez, S.; et al. Phenolic Compounds in Honey and Their Associated Health Benefits: A Review. Molecules 2018, 23, 2322. [CrossRef]

84. Aćimović, M.G.; Milić, N.B. Perspectives of the Apiaceae Hepatoprotective Effects-A Review. Nat. Prod. Commun. 2017, 12, 309-317. [CrossRef]

85. Ajiboye, T.O.; Ajala-Lawal, R.A.; Adeyiga, A.B. Caffeic acid abrogates 1,3-dichloro-2-propanol-induced hepatotoxicity by upregulating nuclear erythroid-related factor 2 and downregulating nuclear factor-kappa B. Hum. Exp. Toxicol. 2019, 38, 1092-1101. [CrossRef]

86. Mu, H.N.; Li, Q.; Fan, J.Y.; Pan, C.S.; Liu, Y.Y.; Yan, L. Caffeic acid attenuates rat liver injury after transplantation involving PDIA3-dependent regulation of NADPH oxidase. Free Radic. Biol. Med. 2018, 129, 202-214. [CrossRef]

87. Hao, R.; Ge, J.; Ren, Y.; Song, X.; Jiang, J.; Waterhouse, D.S.; Li, F. Caffeic acid phenethyl ester mitigates cadmium-induced hepatotoxicity in mice: Role of miR-182-5p/TLR4 axis. Ecotox. Environ. Saf. 2021, 207, 111578. [CrossRef] [PubMed]

88. Chen, S.; Lin, Y.; Miao, L.; Pan, W.; Jiang, W.; Qian, L.; Hao, J.; Xi, B.; Liu, B.; Ge, X. Ferulic acid alleviates lipopolysaccharideinduced acute liver injury in Megalobrama amblycephala. Aquaculture 2021, 532, 735972. [CrossRef]

89. Owumi, S.; Najophe, E.S.; Farombi, E.O.; Oyelere, A.K. Gallic acid protects against Aflatoxin B B $_{1}$-induced oxidative and inflammatory stress damage in rats kidneys and liver. J. Food Biochem. 2020, 44, e13316. [CrossRef] [PubMed]

90. Hussein, R.M.; Anwar, M.M.; Farghaly, H.S.; Kandeil, A.M. Gallic acid and ferulic acid protect the liver from thioacetamideinduced fibrosis in rats via differential expression of miR-21, miR-30 and miR-200 and impact on TGF- $\beta 1 /$ Smad3 signaling. Chem. Biol. Interact. 2020, 324, 109098. [CrossRef]

91. Lee, Y.H.; Lim, W.; Sung, M.K. Carnosic Acid Modulates Increased Hepatic Lipogenesis and Adipocytes Differentiation in Ovariectomized Mice Fed Normal or High-Fat Diets. Nutrients 2018, 15, 1984. [CrossRef] [PubMed]

92. Oguz, A.; Boyuk, A.; Ekinsi, A.; Alabalik, U.; Turkoglou, A.; Tuncer, M.-C.; Ekingen, A.; Deveci, E.; Gültürk, B.; Aday, U. Investigation on the antioxidant effects of rosmarinic acid on liver, lung and kidney in rats; A biochemical and histopathological study. Folia Morpholog. 2020, 2, 288-295. [CrossRef] [PubMed]

93. Meng, X.; Tang, G.Y.; Liu, P.H.; Liu, Q.; Li, H.B.; Zhao, C.J. Antioxidant activity and hepatoprotective effect of 10 medicinal herbs on CCl4-induced liverinjury in mice. World J. Gastroent. 2020, 26, 5629-5645. [CrossRef]

94. Meharie, B.G.; Amare, G.G.; Belayneh, Y.M. Evaluation of Hepatoprotective Activity of the Crude Extract and Solvent Fractions of against $\mathrm{CCl}_{4}$-Induced Hepatotoxicity in Mice. J. Exp. Pharmacol. 2020, 12, 137-150. [CrossRef]

95. Hewage, K.; Nadeeka, I.; Herath, M.; Cho, J.; Kim, A.; Eom, T.K.; Kim, J.S.; Kim, J.B.; Doh, Y.H.; Jee, Y. Phenolic acid and flavonoid-rich fraction of Sasa quelpaertensis Nakai leaves prevent alcohol induced fatty liver through AMPK activation. J. Ethnopharmacol. 2018, 224, 335-348. [CrossRef]

96. Mbarki, S.; Alimi, H.; Bouzenna, H.; Elfeki, A.; Hfaiedh, N. Phytochemical study and protective effect of Trigonella foenum graecum (Fenugreek seeds) against carbon tetrachloride-induced toxicity in liver and kidney of male rat. Biomed. Pharmacother. 2017, 88, 19-26. [CrossRef]

97. Grewal, S.; Sharma, N.; Singh, S.; Kanojia, S.; Thapa, K.; Swami, R.; Rupanshi, G. Molecular docking guided screening of phenolic compounds from Ginko Bilobaas multipotent anti Alzheimer's agents. Plant Arch. 2020, 20, 3297-3308.

98. Habtemariam, S. Protective Effects of Caffeic Acid and the Alzheimer's Brain: An Update. Mini-Rev. Med. Chem. 2017, 17, 667-674. [CrossRef]

99. Zhang, Y.; Wu, O.; Zhang, L.; Wang, O.; Yang, Z.; Liu, J.; Feng, L. Caffeic acid reduces A53T $\alpha$-synuclein by activating JNK/Bcl2-mediated autophagy in vitro and improves behaviour and protects dopaminergic neurons in a mouse model of Parkinson's disease. Pharmacol. Res. 2019, 150, 104538. [CrossRef]

100. Ferreira, R.M.; Dos Santos, A.G.; Martins, N.M.; Fernandes, L.S.; Dos Santos, A.S. Caffeic Acid Phenethyl Ester (CAPE) Protects PC12 Cells from Cisplatin-Induced Neurotoxicity by Activating the NGF-Signaling Pathway. Neurotox. Res. 2018, $34,32-46$. [CrossRef] [PubMed]

101. Gießel, J.M.; Loesche, A.; Csuk, R. Caffeic acid phenethyl ester (CAPE)-derivatives act as selective inhibitors of acetylcholinesterase. Eur. J. Med. Chem. 2019, 177, 259-268. [CrossRef] [PubMed]

102. Bahri, S.; Jameleddine, S.; Shlyonsky, V. Relevance of carnosic acid to the treatment of several health disorders: Molecular targets and mechanisms. Biomed. Pharmacother. 2016, 84, 569-582. [CrossRef] [PubMed]

103. Rehman, S.U.; Ali, T.; Alam, S.I.; Ullah, R.; Zeb, A.; Lee, K.W.; Rutten, B.P.F.; Kim, O.M. Ferulic Acid Rescues LPS-Induced Neurotoxicity via Modulation of the TLR4 Receptor in the Mouse Hippocampus. Mol. Neurobiol. 2019, 56, 2774-2790. [CrossRef] 
104. Mori, T.; Koyama, N.; Tan, J.; Segawa, T.; Maeda, M.; Town, T. Combined treatment with the phenolics (-)-epigallocatechin-3-gallate and ferulic acid improves cognition and reduces Alzheimer-like pathology in mice. J. Biol. Chem. 2019, 294, 2714-2731. [CrossRef]

105. Shabani, S.; Rabiei, Z.; Amini-Khoei, H. Exploring the multifaceted neuroprotective actions of gallic acid, a review. Int. J. Food Prop. 2020, 23, 736-752. [CrossRef]

106. Liu, Y.L.; Hsu, C.C.; Huang, Y.L.; Chang, C.J.; Sun, S.H.; Yuh Lin, A.M. Gallic Acid Attenuated LPS-Induced Neuroinflammation: Protein Aggregation and Necroptosis. Mol. Neurobiol. 2020, 57, 96-104. [CrossRef] [PubMed]

107. Khoshnam, S.E.; Sarkaki, A.; Rashno, M.; Farbood, Y. Memory deficits and hippocampal inflammationin cerebral hypoperfusion and reperfusion in male rats: Neuroprotective role of vanillic acid. Life Sci. 2018, 211, 126-132. [CrossRef]

108. Rizk, Z.A.; Masoud, W.; Maher, O.W. Prophylactic effects of ellagic acid and rosmarinic acid on doxorubicin-induced neurotoxicity in rats. J. Biochem. Mol. Toxicol. 2017, 31, 12. [CrossRef] [PubMed]

109. Salau, V.F.; Erukainure, O.L.; Ibeji, C.U.; Olasehinde, T.A.; Koorbanally, N.A. Vanillin and vanillic acid modulate antioxidant defense system via amelioration of metabolic complications linked to $\mathrm{Fe}^{2+}$-induced brain tissues damage. Metab. Brain Dis. 2020, 35, 727-738. [CrossRef] [PubMed]

110. Anand, A.; Khurana, R.; Wahal, N.; Mahajan, S.; Mehta, M.; Satija, S.; Sharma, N.; Vyas, M.; Khurana, N. Vanillin: A comprehensive review of pharmacological activities. Plant Arch. 2019, 1000-1004.

111. El-Sawi, S.A.; Ezzat, S.A.; Aly, H.F.; Merghany, R.M.; Meselhy, M.R. Neuroprotective effect of Salvia splendens extract and its constituents against $\mathrm{AlCl}_{3}$-induced Alzheimer's disease in rats. Adv. Tradit. Med. 2020, 20, 381-393. [CrossRef]

112. Khoshnam, S.E.; Farbood, Y.; Fathi Moghaddam, H.; Sarkaki, A.; Badavi, M.; Khorsandi, L. Vanillic acid attenuates cerebral hyperemia, blood-brain barrier disruption and anxiety-like behaviors in rats following transient bilateral common carotid occlusion and reperfusion. Metab. Brain Dis. 2018, 33, 785-793. [CrossRef]

113. Panzella, L.; Eidenberger, T.; Napolitano, A. Anti-Amyloid aggregation activity of black sesame pigment: Toward a Novel Alzheimer's Disease Preventive Agent. Molecules 2018, 23, 676. [CrossRef]

114. Liang, Z.; Yuan, Z.P.; Ding, T.; Yan, L.; Ling, L.; Zhou, X.F.; Zeng, Y.Q. Neuroprotective Effect of Fagopyrum dibotrys Extract against Alzheimer's Disease. Evid.-Based Complement. Alternat. Med. 2017, 2017, 3294586. [CrossRef]

115. Yilmaz, Y.; Toledo, R.T. Health aspects of functional grape seed constituents. Trends Food Sci. Technol. 2004, 9, 422-433. [CrossRef]

116. Kaur, N.; Bains, A.; Kaushik, R.; Dhull, S.B.; Chawla, P. Review on Antifungal Efficiency of Plant Extracts Entrenched Polysaccharide-Based Nanohydrogels. Nutrients 2021, 13, 2055. [CrossRef]

117. Semeniuc, C.A.; Socaciu, M.A.; Socaci, S.A.; Muresan, V.; Fogarasi, M.; Rotar, A.M. Chemometric Comparison and Classification of Some Essential Oils Extracted from Plants Belonging to Apiaceae and Lamiaceae Families Based on Their Chemical Composition and Biological Activities. Molecules 2018, 23, 2261. [CrossRef]

118. Liu, J.; Du, C.; Beaman, H.T.; Monroe, M.B. Characterization of Phenolic Acid Antimicrobial and Antioxidant Structure-Property Relationships. Pharmaceutics 2020, 12, 419. [CrossRef]

119. Elegir, G.; Kindl, A.; Yilmaz, Y.; Orland, S.M. Development of antimicrobial cellulose packaging through laccase-mediated grafting of phenolic compounds. Enzym. Microb. Technol. 2008, 43, 84-92. [CrossRef]

120. Merkl, R.; Hrádková, I.; Filip, V.; Šmidrkal, J. Antimicrobial and antioxidant properties of phenolic acids alkyl esters. Czech. J. Food Sci. 2010, 28, 275-279. [CrossRef]

121. Wu, Y.H.; Zhang, B.Y.; Qiu, L.P.; Guan, R.F.; Ye, Z.H.; Yu, X.P. Structure Properties and Mechanisms of Action of Naturally Originated Phenolic Acids and Their Derivatives against Human Viral Infections. Curr. Med. Chem. 2017, 24, 4279-4302. [CrossRef] [PubMed]

122. Paulo, F.; Santos, L. Microencapsulation of caffeic acid and its release using a w/o/w double emulsion method: Assessment of formulation parameters. Drying Techn. 2019, 37, 950-961. [CrossRef]

123. Langland, J.; Jacobs, B.; Wagner, C.E.; Ruiz, G.; Cahill, T.M. Antiviral Activity of Metal Chelates of Caffeic Acid and Similar Compounds towards Herpes Simplex, VSV-Ebola Pseudotyped and Vaccinia Viruses. Antiviral Res. 2018, 160, 143-150. [CrossRef]

124. Zhang, E.; Zhai, T.; Haide, S.; Li, Y.; Huang, H.J. Synergistic Effect of Chlorogenic Acid and Caffeic Acid with Fosfomycin on Growth Inhibition of a Resistant Listeria monocytogenes Strain. ACS Omega 2020, 5, 7537-7544. [CrossRef]

125. De Camargo, A.C.; Regitano-d'Arce, M.A.B.; Rasera, G.B.; Canniatti-Brazaca, S.G.; Do Prado-Silva, L.; Alvarenga, L.O.; Sant'Ana, A.S.; Shahidi, F. Phenolic acids and flavonoids of peanut by-products: Antioxidant capacity and antimicrobial effects. Food Chem. 2017, 237, 538-544. [CrossRef] [PubMed]

126. Baidoo, M.F.; Mensah, A.Y.; Ossei, P.P.S.; Kwatia, E.A.; Amponsah, I.K. Wound healing, antimicrobial and antioxidant properties of the leaf and stem bark of Entada africana Guill. \& Perr. S. Afr. J. Bot. 2020, 137, 52-59. [CrossRef]

127. Attia, Y.A.; Alagawany, M.M.; Farag, M.R.; Alkhatib, F.M.; Khafaga, A.F.; Abdel-Moneim, A.M.; Asiry, A.; Mesalam, N.M.; Shafi, M.E.; Al-Harthi, A.; et al. Phytogenic Products and Phytochemicals as a Candidate Strategy to Improve Tolerance to Coronavirus. Front. Vet. Sci. 2020, 7, 573159. [CrossRef] [PubMed]

128. Mani, J.S.; Johnson, J.B.; Steel, J.C.; Broszczak, D.A.; Neilsen, P.M.; Walsh, K.B.; Naiker, M. Natural product-derived phytochemicals as potential agents against coronaviruses: A review. Virus Res. 2020, 284, 197989. [CrossRef] [PubMed]

129. Elfiky, A.A. Natural products may interfere with SARS-CoV-2 attachment to the host cell. J. Biomol. Struct. Dyn. 2020, 1-10. [CrossRef] 
130. Kumar, V.; Dhanjal, J.K.; Kaur, J.; Bhargava, P.; Kaul, A.; Wang, J.; Zhang, H.; Kaul, S.C.; Wadhwa, R.; Sundar, D. Withanone and Withaferin-A are predicted to interact with transmembrane protease serine 2 (TMPRSS2) and block entry of SARS-CoV-2 into cells. J. Biomol. Struct. Dyn. 2020, 39, 3194-3203. [CrossRef]

131. Khalil, A.; Tazeddinova, D. The upshot of Polyphenolic compounds on immunity amid COVID-19 pandemic and other emerging communicable diseases: An apprais. Nat. Prod. Bioprosp. 2020, 10, 411-429. [CrossRef]

132. Weng, J.R.; Lin, C.S.; Lai, H.C.; Lin, Y.P.; Wang, C.Y.; Wang, C.Y.; Tsai, Y.C.; Wu, K.C.; Huang, S.H.; Lin, C.W. Antiviral activity of Sambucus FormosanaNakai ethanol extract and related phenolic acid constituents against human coronavirus NL63. Virus Res. 2019, 273, 197767. [CrossRef]

133. Adem, S.; Eyupoglu, V.; Sarfraz, I.; Rasul, A.; Zahoor, A.F.; Ali, M.; Abdalla, M.; Ibrahim, I.M.; Elfiky, A.A. Caffeic acid derivatives (CAFDs) as inhibitors of SARS-CoV-2: CAFDs-based functional foods as a potential alternative approach to combat COVID-19. Phytomedicine 2020, 85, 153310. [CrossRef] [PubMed]

134. Gasparotto Junior, A.; Lima Tolouei, S.A.; Dos Reis Lívero, F.A.; Gasparotto, F.; Boeing, T.; de Souza, P. Natural Agents Modulating ACE-2: A Review of Compounds with Potential against SARS-CoV-2 Infections. Curr. Farm. Des. 2021, 27, 1588-1596. [CrossRef] 